\title{
Leprosy Transmission in Amazonian Countries: Current Status and Future Trends
}

\author{
Roxane Schaub ${ }^{1,2}$ (1) Charlotte Avanzi ${ }^{3,4} \cdot$ Pushpendra Singh ${ }^{5,6} \cdot$ Alberto Paniz-Mondolfi $^{7,8}$ - Nora Cardona-Castro ${ }^{9}$. \\ Pedro Legua ${ }^{10}$. Lucibel Crespo ${ }^{11}$. Karin Sewpersad ${ }^{12}$. John Jairo Dávila ${ }^{13}$. Josafá Barreto ${ }^{14}$. Purna Dwivedi ${ }^{5}$. \\ Heather Morris-Wilson ${ }^{15} \cdot$ Maria Paredes Larrea ${ }^{16,17} \cdot$ Carolina Talhari $^{18} \cdot$ Ramanuj Lahiri $^{19} \cdot$ Richard W. Truman $^{20}$. \\ Rodolphe E. Gozlan ${ }^{21}$ • Pierre Couppié ${ }^{2,22} \cdot$ Benoit de Thoisy ${ }^{23}$
}

Published online: 19 May 2020

(C) The Author(s) 2020

\begin{abstract}
Purpose of Review Leprosy is one of the first pathologies described in the history of mankind. However, the ecology, transmission, and pathogenicity of the incriminated bacilli remain poorly understood. Despite effective treatment freely distributed worldwide since 1995, around 200,000 new cases continue to be detected yearly, mostly in the tropics. This review aims to discuss the unique characteristics of leprosy in Amazonian countries, which exhibit a very heterogeneous prevalence among human and animal reservoirs.

Recent Findings Groundbreaking discoveries made in the last 15 years have challenged the dogmas about leprosy reservoirs, transmission, and treatment. The discovery of a new leprosy causative agent in 2008 and the scientific proof of zoonosis transmission of leprosy by nine-banded armadillos in the southern USA in 2011 challenged the prospects of leprosy eradication. In the Amazonian biome, nine-banded and other armadillo species are present but the lack of large-scale studies does not yet allow accurate assessment of the zoonotic risk. Brazil is the second country in the world reporting the highest number of new leprosy cases annually. The disease is also present, albeit with different rates, in all neighboring countries. Throughout the Amazonian biome, leprosy is mainly found in hyperendemic foci, conducive to the emergence and transmission of drug-resistant strains.

Summary The deepening of current knowledge on leprosy reservoirs, transmission, and therapeutic issues, with the One Health approach and the help of molecular biology, will allow a better understanding and management of the public health issues and challenges related to leprosy in Amazonia.
\end{abstract}

Keywords Leprosy $\cdot$ South America $\cdot$ Amazonia $\cdot$ Guianas $\cdot$ Armadillos $\cdot$ Mycobacterium leprae

\section{Introduction}

Leprosy, also called Hansen's disease, is a chronic mycobacterial infection of the peripheral nerves and skin that generally manifests as loss of sensation and skin patches. If left untreated, the resulting nerve damage may ultimately lead to

This article is part of the Topical Collection on Amazonian Diseases in Isolate Populations

Roxane Schaub

roxane.schaub@gmail.com

Benoit de Thoisy

bdethoisy@pasteur-cayenne.fr

Extended author information available on the last page of the article disability and disfigurement, which are the main factors responsible for social stigma against leprosy patients. The disease presents over a broad clinical and histopathological spectrum [1] and is caused by the closely related pathogens Mycobacterium leprae and M. lepromatosis [2]. These obligate intracellular bacteria are clinically indistinguishable and uncultivable in vitro, but molecular diagnostic tests were recently developed using species-specific primers for polymerase chain reaction-based detection [3, 4]. Both pathogens are cultivated in vivo in footpads of conventional and immunodeficient mouse strains (MFP) [3], and M. leprae in nine-banded armadillos [5]. However, only a few laboratories worldwide have this expertise to cultivate leprosy bacilli and their slow growth in vivo (12 days doubling time) impairs routinely usage of these models. 
Despite a steady but slow decrease in the new case detection rate (NCDR) of leprosy over the last three decades, associated with widespread implementation of multi-drug therapy (MDT), more than 200,000 new cases of leprosy were reported worldwide in 2018, mostly in the intertropical band [6]. Leprosy remains a significant health problem in several countries, including India and Brazil, which individually report the highest number of new leprosy cases each year with 120,334 and 28,660 respectively in 2018 [6].

Numerous unanswered questions remain regarding its transmission and ecology, as well as its zoonotic and sapronotic reservoirs. The bacilli are mainly transmitted from human to human probably through nasal droplets [7]. Persons living with an untreated multibacillary case (MB) are at higher risk for infection than those without such exposure [8]. However, the majority of new cases cannot recall interaction with a known index case, and several other potential transmission models are now being scrutinized, including zoonotic transmission.

The Amazonian biome is a vast humid tropical ecosystem extending across northwestern Brazil and parts of the following Andean countries: Venezuela, Colombia, Peru, Ecuador, and Bolivia. These countries also have regions with drier tropical ecosystems and mountainous areas. The Amazonian biome also covers the Guiana Shield located in the northern coast of South America: Guyana, Suriname, and French Guiana. In 2018, new leprosy cases were reported in all these countries [6]. Interestingly, tropical South America is also one of the principal habitats of armadillo species, including ninebanded armadillos, which has been confirmed to be a major non-human reservoir of $M$. leprae [9].

In this review, we aim to discuss the unique characteristics of leprosy epidemiology in the Amazonian countries that combine high and low prevalence areas, as well as the potential role of the sole animal reservoir known to date in this region. This is the first review focusing on global leprosy epidemiology in the Amazonian biome and its surroundings.

\section{Epidemiology of Human Leprosy in the Amazonian Countries}

\section{A Contrasted Continental Pattern}

In the Americas, 93\% of new leprosy cases are detected in Brazil, followed by Paraguay, Colombia, Argentina, and Venezuela [6]. Except for Brazil, all countries reported in this review achieved the goal of leprosy elimination as defined by the World Health Organization (WHO) of $<1 / 10,000$ inhabitants (Table 1). Nevertheless, except for Bolivia and Ecuador, new cases continue to be detected among children [6], suggesting that leprosy transmission remains active in the overall region
[11]. Andean countries have an approximatively 50-fold lower NCDR compared to Brazil and an approximatively 5-fold lower rate compared to the Guiana Shield countries. The distribution of the NCDR is also contrasted within each country (Fig. 1a).

Leprosy caused by $M$. lepromatosis is rarely reported worldwide but molecular identification of the etiological agent is usually not routinely performed. So far, the species has mostly been identified in Mexico, the Caribbean, and the United States of America (USA), and has been associated with few cases in Brazil [3, 4]. Given this geographical coverage and the similar clinical outcome in both species, it is likely that M. lepromatosis might also be present in other Amazonian countries, but epidemiological investigations are required to improve our knowledge of the distribution of this particular leprosy agent.

\section{Regional Epidemiological Patterns}

\section{Brazil}

According to the Brazilian Ministry of Health, the spatial distribution of leprosy is highly heterogeneous, with an annual NCDR ranging from 0.1 to $13.8 / 10,000$ inhabitants in the states of Rio Grande do Sul (South) and Mato Grosso (partly in the Amazonian region) in 2018, respectively. The average NCDR in the Amazonian states (4.7/10,000 inhabitants) is 4.2-fold higher compared to the non-Amazonian states in Brazil (1.1/10,000 inhabitants). Additionally, there is evidence of high rates of hidden prevalence of leprosy and subclinical infection among schoolchildren in the Amazonian region, which represent active foci of infection [25, 26]. During the last 2 years, improved efforts of active search have increased the NCDR from 1.22 in 2016 to $1.37 / 10,000$ inhabitants in 2018 [27].

\section{Andean Countries With Amazonian Regions}

Leprosy was eliminated (according to the WHO definition) in these countries before 2011 [28]. In 2018, the NCDR was ranging from 0.01 in Peru to $0.08 / 10,000$ inhabitants in Venezuela (Table 1). However, the persistence of transmission pockets has prevented eradication of the disease at sub-national level in Colombia and Venezuela. A high burden of the disease has persisted in 13 out of 32 regions in Colombia in 2016 [29] and 5 out of 23 states in Venezuela $[10,30]$. In contrast, no noticeable similar transmission pockets have been reported in Ecuador, Bolivia, and Peru sub-national levels. The proportion of new cases diagnosed with grade 2 disability in these countries, however, is alarming with $5 \%$, $19 \%$, and $29 \%$, respectively (Table 1 ). These observations may be influenced by weak health care networks 
Table 1 Leprosy situation in 2018 in South America by country

\begin{tabular}{|c|c|c|c|c|c|c|}
\hline & $\begin{array}{l}\text { New cases } \\
\text { in } 2018(\mathrm{Nb})\end{array}$ & $\begin{array}{l}\text { NCDR } 2018 \\
\text { (per 10,000 inhabitants) }\end{array}$ & $\begin{array}{l}\text { MB in new } \\
\text { cases }(\%)\end{array}$ & $\begin{array}{l}\text { Children }<14 \text { years } \\
\text { in new cases }(\%)\end{array}$ & $\begin{array}{l}\text { Grade } 2 \text { disability in } \\
\text { new cases }(\%)\end{array}$ & $\begin{array}{l}\text { Relapse } \\
\text { cases }(\mathrm{Nb})\end{array}$ \\
\hline Amazonian countries & 29,498 & 0.84 & 77 & 6 & 7 & 1930 \\
\hline Brazil & 28,660 & 1.37 & 77 & 6 & 7 & 1840 \\
\hline Andean countries & 750 & 0.05 & 78 & 6 & 10 & 86 \\
\hline Colombia & $383^{\mathrm{a}}$ & 0.08 & 69 & $10^{\mathrm{a}}$ & 10 & 47 \\
\hline Venezuela & 245 & $0.08^{\mathrm{b}}$ & $86^{\mathrm{b}}$ & 3 & 6 & $22^{\mathrm{b}}$ \\
\hline Bolivia & 52 & 0.05 & 83 & 0 & 19 & 1 \\
\hline Ecuador & 42 & 0.02 & 98 & 0 & 5 & 10 \\
\hline Peru & 28 & 0.01 & 100 & 4 & 29 & 6 \\
\hline Guiana Shield & 88 & 0.54 & 74 & 13 & 19 & 4 \\
\hline Guyana & 50 & 0.64 & 84 & 14 & 26 & 0 \\
\hline Suriname & 24 & 0.42 & 63 & 17 & 8 & 4 \\
\hline French Guiana $^{\mathrm{c}}$ & 14 & 0.50 & 57 & 0 & 14 & 0 \\
\hline Non-Amazonian countries & 627 & 0.09 & 87 & 13 & 3 & $9 \%$ \\
\hline Paraguay & 345 & 0.50 & 88 & 3 & 12 & 52 \\
\hline Uruguay & 6 & 0.02 & 100 & 0 & 17 & 0 \\
\hline Chile & 7 & 0.004 & 57 & 0 & 0 & 0 \\
\hline Argentina & 269 & 0.06 & 87 & 2 & 14 & 2 \\
\hline
\end{tabular}

Reference: [6]; unless otherwise specified: ${ }^{\mathrm{a}} \mathrm{N}$. Cardona-Castro, unpublished data; ${ }^{\mathrm{b}}[10]$; ${ }^{\mathrm{c}} \mathrm{P}$. Couppié, unpublished data $N b$ number, $N C D R$ new case detection rate, $M B$ multi-bacillary

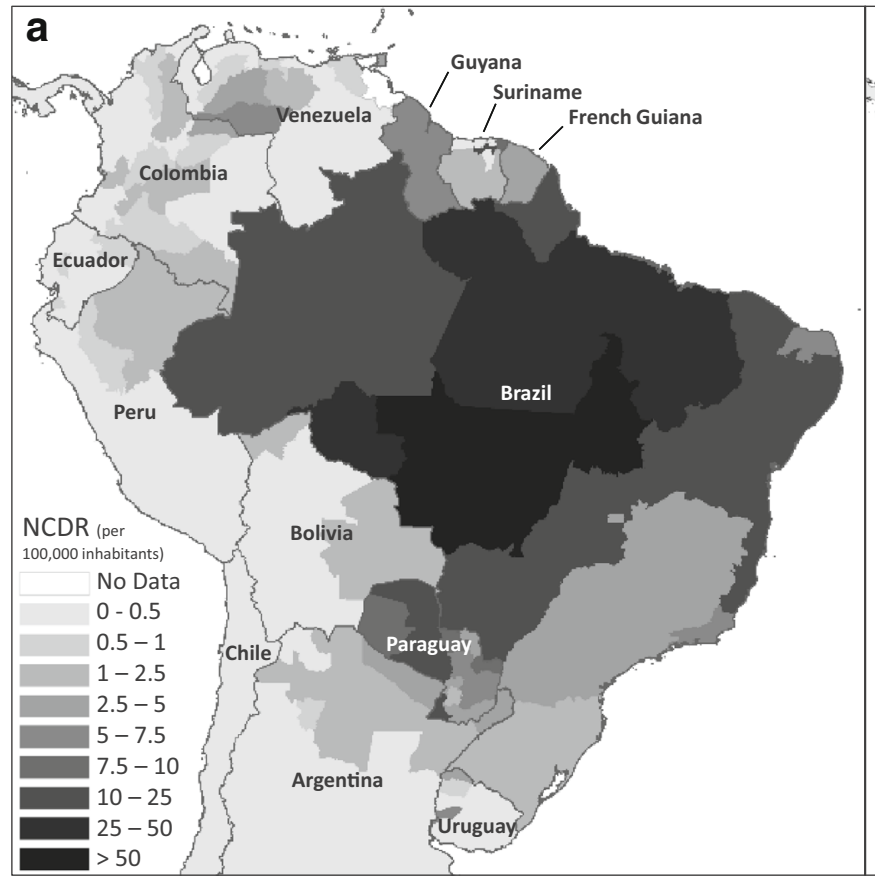

Fig. 1 Leprosy new case detection rates (NCDR) in human population in 2018 and armadillo Mycobacterium leprae infection point-estimate prevalence in Amazonian countries. a Map of leprosy NCDR per 100,000 inhabitants in 2018, per state. NCDR is reported by state/ region for each country, except Guyana and French Guiana. NCDR are for 2018, except 2017 for Ecuador. b Map of the armadillo's species range

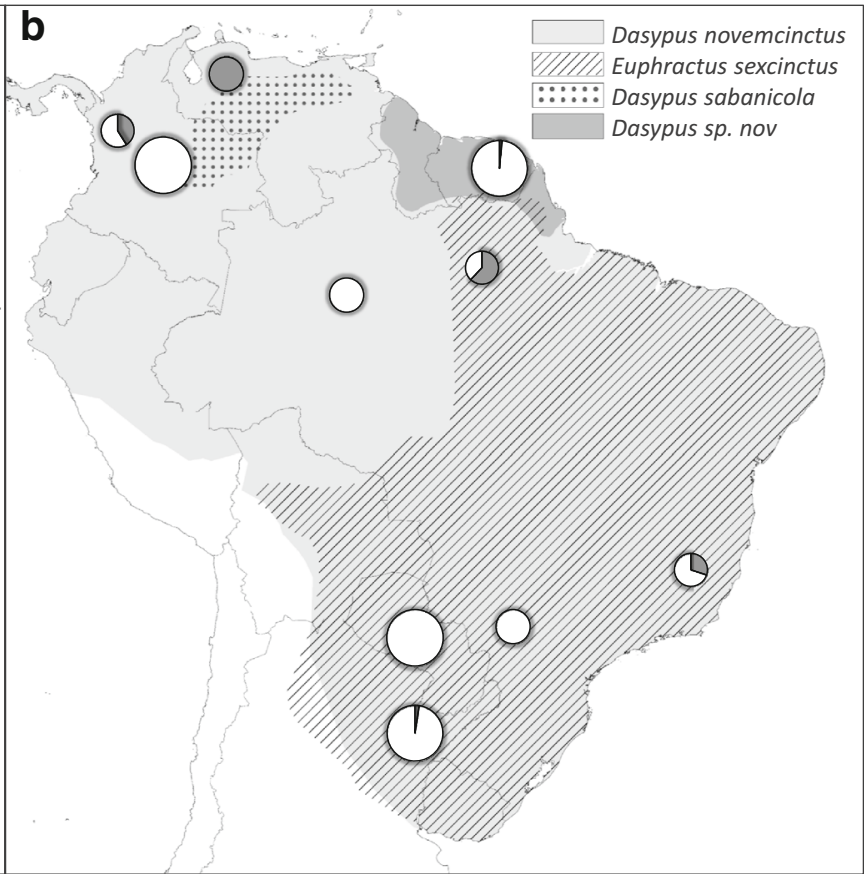

(only species known to be naturally infected by M. leprae) and research studies on leprosy detection in wild armadillos. Larger circles indicate studies with at least 50 specimens analyzed. The proportion of positive specimens appear in gray. Details of represented investigations are in Table 2 
and a lack of awareness about leprosy among dermatologists and the general population, contributing to underdetection of the real NCDR and delayed diagnosis in these countries.

\section{The Guiana Shield}

Guyana, Suriname, and French Guiana have a NCDR of 0.42, 0.50 , and 0.64/10,000 inhabitants, respectively (Table 1). In French Guiana, only $22 \%$ of new cases from the period 20072014 were considered autochthonous. Some 56\% of the cases originated from Brazil, mainly among illegal gold miners [31], who are subject to harsh living conditions, poor health, and poor access to health care [32]. Similar conclusions were recently drawn in Guyana, which has seen a re-emergence of leprosy following human migration from endemic regions [33]. In 2018 , patients diagnosed with a grade 2 disability represented $8 \%, 14 \%$, and $26 \%$ of new leprosy cases, respectively, in Suriname, French Guiana, and Guyana (Table 1), an unfortunate indicator that there is insufficient awareness about leprosy in the community.

\section{The Emergence of Regional Antimicrobial Resistance}

In the face of the development of resistance following dapsone monotherapy, the $\mathrm{WHO}$ has recommended the use of MDT regimen since 1981 [34]. MDT is efficient and includes a combination of dapsone, rifampicin, and clofazimine. However, dapsone and rifampicin drug-resistant strains are still circulating in the population following the monotherapy era [35*0]. Resistance to ofloxacin, a second-line drug that is used in the case of rifampicin resistance or intolerance, is also subject to emergence, perhaps because of its routine use in many other common diseases [36]. Minocycline and clarithromycin are the only other drugs used in case of resistance or intolerance to rifampicin [36]. MFP assay is the gold standard method for antimicrobial susceptibility testing in leprosy. However, this method is time-consuming (requiring 6 to 9 months to complete) and requires highly trained technicians. Therefore, the method is not suitable for routine use in a surveillance program, and molecular screening techniques are now more the norm. Molecular assays for drug susceptibility screening have been developed for rifampicin, dapsone, and ofloxacin [37]. The mechanism of action of clofazimine remains to be elucidated and, so far, $M$. leprae resistance to minocycline and clarithromycin has not yet been detected in leprosy patients.

Over the last decade, a surveillance program implemented by WHO investigated the rate of $M$. leprae drug resistance to dapsone, rifampicin, and ofloxacin worldwide among relapse and new leprosy cases, with special emphasize on rifampicin [35••]. Rifampicin is the cornerstone drug of leprosy treatment due to its rapid bactericidal activity, so MDT efficiency is severely compromised in case of resistance. The 2009-2015 report showed that Brazil, Colombia, and India were among countries reporting more than five rifampicin-resistant cases [35••]. In Colombia, rifampicin- and dapsone-resistant cases are reported in relapse patients (9/37) previously treated with dapsone monotherapy [38], while resistances were found in both primary (5/32) and relapse (27/321) cases in Brazil [39]. Recent literature also reported dapsone and ofloxacin resistance as well as circulation of multidrug-resistant strains in Brazil [40••]. In a hyper-endemic village that was once a leprosarium in Pará (Brazilian amazon), $43 \%$ of patients had a $M$. leprae strain resistant to one or more anti-leprosy drugs, in both new patients and relapse cases. Furthermore, the authors observed both familial and community-level clustering of resistant strains in this village, indicating that this particular setting with high leprosy prevalence in a genetically susceptible population was driving hyper-endemicity with the emergence and transmission of drug-resistant $M$. leprae strains [41].

Except for Brazil and Colombia, none of the Amazonian countries were part of the drug resistance surveillance program [35••]. In Venezuela and Bolivia, during a 3-year survey published in 2011, with 197 patients and 10 patients respectively, only one case of dapsone resistance-associated mutation was observed [42]. No information is available for Ecuador, Peru, nor Suriname. Still, all three countries showed a high number of relapse cases compared to their low NCDR, with 10, 6, and 4 respectively in 2018 (Table 1). These data suggest the possible presence of drug-resistant strains as in Colombia (12\% relapse cases) or reflect poor treatment compliance in the patient.

Reinfection might also be a major driver of the persistence of (hyper)endemicity in the Amazonian region [43]. M. leprae strains from the same patients or closely related individuals may differ only with few single nucleotide polymorphisms (SNPs) $[40 \bullet, 44]$ and these differences can be best investigated through whole-genome sequencing (WGS) approach [45] which are currently not performed routinely.

\section{Environmental Sources of Leprosy Bacilli}

\section{Armadillo as a M. leprae Reservoir}

One of the major features of leprosy in the Americas is the presence of nine-banded armadillos (Dasypus novemcinctus), the most important non-human M. leprae reservoir known to date. Naturally infected nine-banded armadillos were first discovered in 1975 in the USA [46]. The presence of M. leprae among armadillos was later confirmed in Mexico [47], nonAmazonian parts of Brazil [12, 15, 17-19, 48], Argentina [49], and Colombia [20], and recently was confirmed in the Brazilian Amazonia [14•].

The first evidence of zoonotic leprosy transmission from nine-banded armadillos to humans was provided by Truman 
et al. in 2011, who showed that $64 \%$ of patients from the same areas who had a possible endemic exposure to armadilloborne $M$. leprae were carrying the same $M$. leprae strain as $88 \%$ of the naturally infected nine-banded armadillos in Southern USA [50••]. Later, a second zoonotic strain was discovered in Florida, where $42 \%$ of patients harbored one of the two known zoonotic strains [51]. The zoonotic transmission risk is likely to increase in the USA, as armadillo range is expanding, leprosy is spreading in armadillo populations, and armadillo-human interactions are intensifying as a result of increasing urbanization [52]. High density and humidity are the only factors linked to $M$. leprae prevalence in nine-banded armadillos so far [9].

There are 9 described armadillo species in Amazonia and the Guianas [53], and a tenth in the Guiana Shield, Dasypus sp. nov., pending description [54]. Apart from D. novemcinctus, at least three other species may be naturally infected with M. leprae (Fig. 1b): Euphractus sexcinctus [12, 15], Dasypus sp. nov. [22], and D. sabanicola (A. Paniz-Mondolfi, P. Singh; unpublished data). In South America, point-prevalence rates of $M$. leprae infection in wild armadillos range from 0 to $100 \%$ (Table 2). D. septemcinctus is experimentally susceptible to $M$. leprae infection and would need further assessment in wild animals [55].

To date, the precise mode of transmission of $M$. leprae from armadillos to humans remains unclear. The bacilli may pass through direct contact with armadillo skin, blood, and body fluids, perhaps through hunting, cleaning, and preparing the meat $[5,14,56]$. The bacilli may be shared, through the respiratory routes [57], or spread by contact when keeping animals in an enclosure to purge or fatten it $[14,56]$, or for traditional medicine or using parts of it to make objects [58]. Several studies have evaluated the risk of leprosy from eating armadillo meat but the results remain inconclusive [48, 59-62]. Furthermore, the outcome of these studies should be taken with caution because of potential biases and given that risk assessments may be impacted by the high proportion of people naturally immune to leprosy [63] and the very long incubation period [64].

Despite a ban by most South American countries on hunting armadillos, except for native populations, the consumption of armadillo meat is widespread. In Brazil, armadillo hunting is frequent for both food and leisure [56]. In French Guiana, it is legal to hunt and sell Dasypus armadillo meat. In Venezuela, consumption of armadillo as well as other game has been traditional in many areas and has increased in the context of the humanitarian crisis.

We lack important information to understand the discrepancies observed in animal $M$. leprae infection prevalence in similar ecosystems [5]. Furthermore, pockets of high endemicity and high animal $M$. leprae infection prevalence do not necessarily overlap [13], part of which could be attributable to the role of host genetic susceptibility to leprosy which may vary in different ethnic groups/populations [65-68]. The assessment of animal reservoir extension and drivers of animal $M$. leprae infection prevalence and susceptibility [9], as well as the animal-to-animal and animal-to-human transmission pathways [69] including the role of the environment in its transmission, would require further investigation.

\section{Questioned Role of Other Species}

The recent discovery of red squirrels (Sciurus vulgaris) infected with $M$. leprae and M. lepromatosis in the British Isles [70••] pushes even further our understanding of leprosy ecology and suggests the existence of other reservoirs of the bacilli. In the Amazonian and Guiana Shield regions, where the biodiversity is among the richest in the world [71], molecular surveys in lowland tapirs (Tapirus terrestris), owl (Aotus trivirgatus), and capuchin (Sapajus apella) monkeys and margay cats (Leopardus wiedii) in Mato Grosso state in Brazil have detected $M$. leprae DNA from nasal swabs [72]. The nose may serve as a filter of the environment and there is no other evidence that these animals may serve as reservoir of the bacilli, but detecting $M$. leprae DNA on nasal mucosa reinforces the hypotheses of an environmental presence of the bacilli made possible by excretion from human and animal carriers.

\section{The Role of Soil and Water}

Indirect contact with leprosy patients through the bacilli they shed to the environment, such as when bathing [60], could facilitate transmission and is one of the possible explanations for the disease persistence in human despite the effectiveness of MDT [73]. M. leprae DNA has been found in water and soil samples taken from the immediate peridomicile area of leprosy patients in India [74-76], as well as in soil samples of leprosy patients' house in Bangladesh [77•]. In the Northeastern Brazilian state of Ceará, M. leprae DNA was found in $54.4 \%$ of natural water sources (lakes, dams, streams, and wells) used by locals [78]. As many as $76.7 \%$ of these samples were harboring viable $M$. leprae [79].

Another hypothesis is indirect transmission of leprosy bacilli through soil contaminated by infected animals, to which people can be exposed when cultivating or gardening [51], or hunting [56]. Armadillos dig burrows for shelter and feeding. $M$. leprae DNA has been detected in armadillo burrow soil in Suriname [77•]. Shedding leprosy bacilli from infected armadillos might occur during digging and sheltering, leading to accumulation of bacilli in burrows where they remain protected from sunlight and less subject to desiccation [80].

It is unclear how an obligate intracellular parasite like M. leprae, which cannot be cultivated on artificial media in 


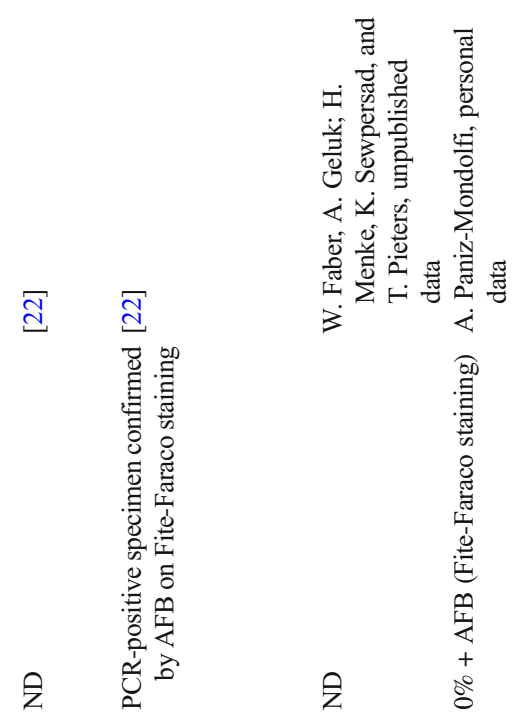

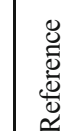

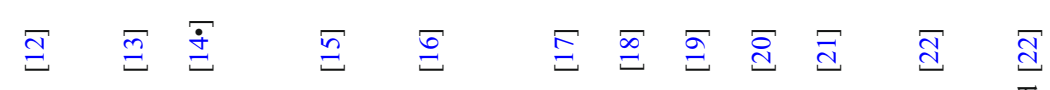

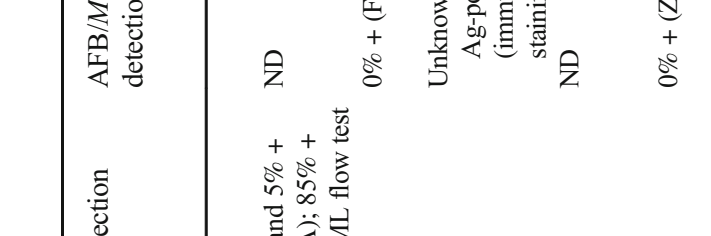

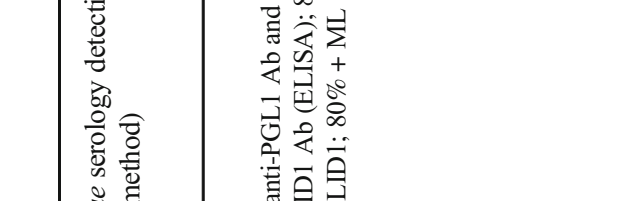

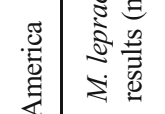

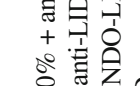

言

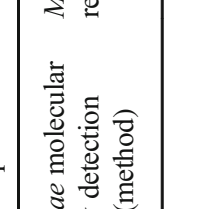

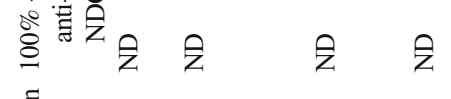

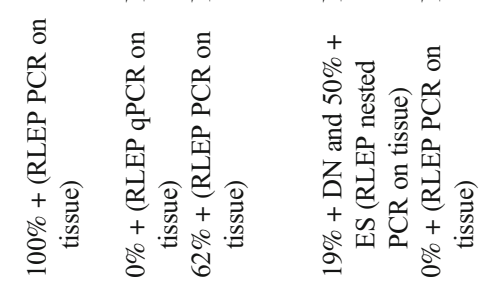

之云之总

을

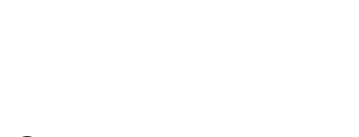

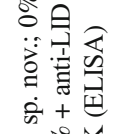

在苞

i :

可获

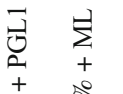

焉记

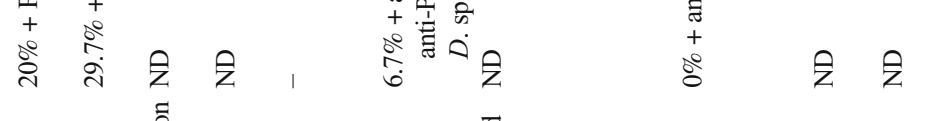

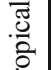
$<5$

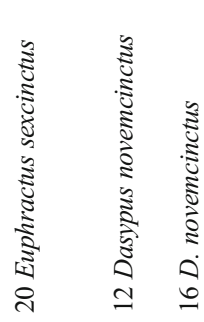

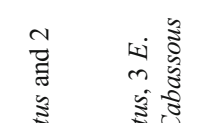

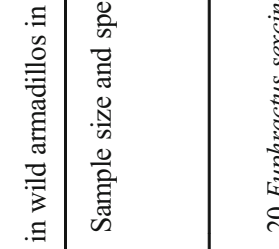

总

휼

$\frac{2}{2}$

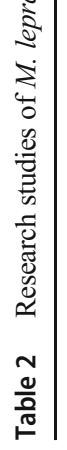

กำ

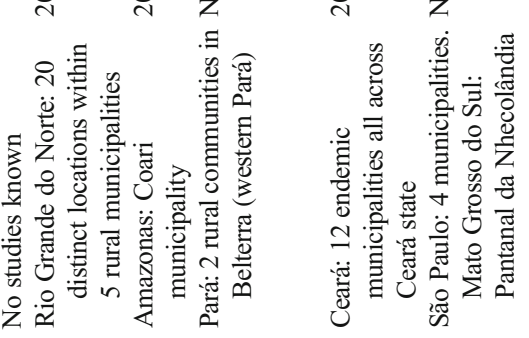

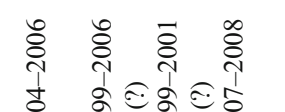

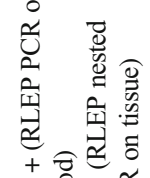

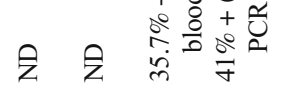

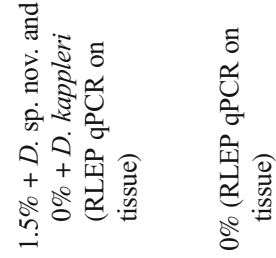

定

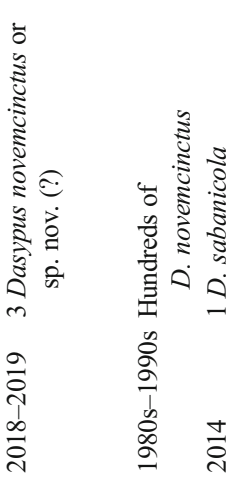

II
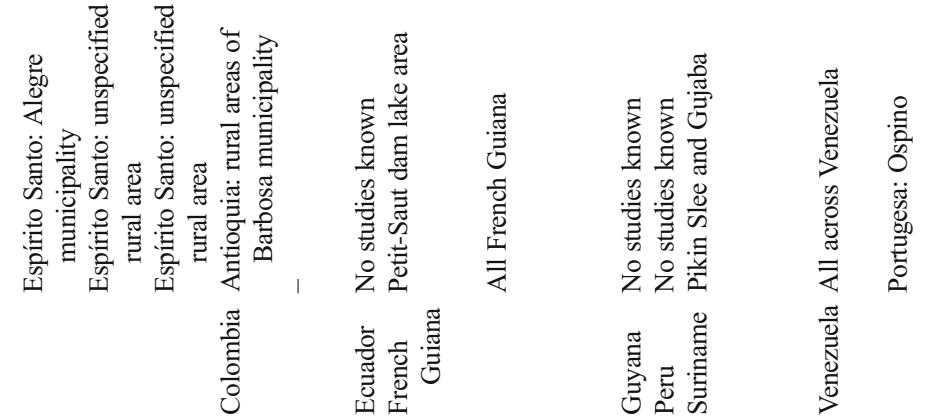


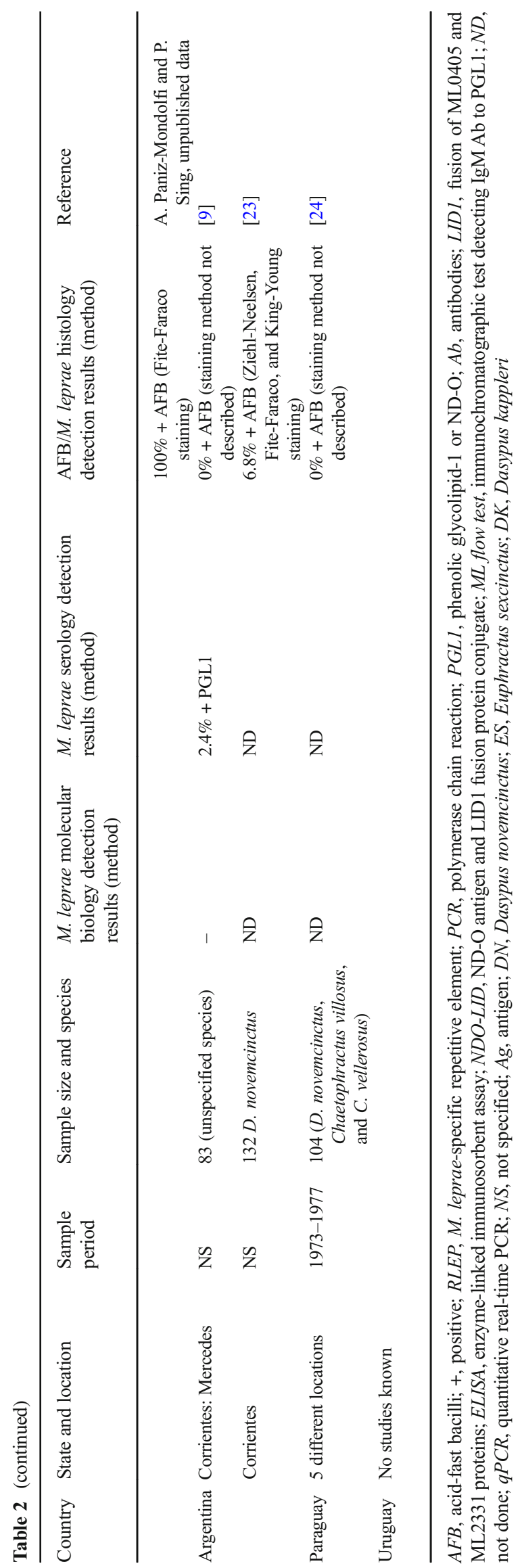

the laboratory, might survive in the natural environment. Recently, however, it was shown that free-living amoebas could provide a convenient refuge for $M$. leprae by ingesting the bacilli shed from infected human/animal hosts. Recent studies show that ingested bacilli can remain viable for extended durations and could enable ongoing transmission [76]. Ubiquitous environmental amoebas like Acanthamoeba and Vermamoeba have been found in armadillo burrows [81] that might benefit bacterial survival. Acanthamoeba castellanii are capable of ingesting M. leprae and after $72 \mathrm{~h}$, the extracted bacilli's viability is intact [82]. In addition, M. leprae can remain virulent for at least 35 days and viable up to 8 months after phagocytosis in encysted A. castellanii and A. polyphaga [83]. Infected amoebas have not yet been observed in nature. Nevertheless, with its very high humidity throughout the year [84], Amazonia might provide a perfect habitat for a prolonged survival of the bacilli in the environment [85].

The role of blood-sucking arthropods is also under scrutiny, and to date, kissing bugs and ticks, parasites of both humans and armadillos, have been experimentally demonstrated to be capable of ingesting M. leprae. Bacilli can remain alive in their digestive tract for at least several days and later excreted. Experimentally, kissing bugs from the Rhodnius genus are capable of excreting viable and infective M. leprae in their feces [86]. Some kissing bugs feed on armadillos, including species from the terrestrial genera Panstrongylus [87], Rhodnius [88], and Triatoma [89-92], and their habitat is associated with armadillo burrows [93, 94]. Whether kissing bugs from the Panstrongylus and Triatoma genera are also able to excrete $M$. leprae is not yet known. Ticks, mainly from the genera Amblyomma, are also frequent parasites of armadillos in Brazil $[95,96]$ and in French Guiana [97]. Ticks may ingest viable $M$. leprae while taking blood meals as armadillos do periodically show bacteremia [5]. Experimentally, ticks from the Amblyomma sculptum species are capable of vertical transmission of M. leprae from the infected female to her larvae and are therefore potential competent vectors of M. leprae and may be implicated in transmission between armadillos and to humans [98]. However, the presence of different species of kissing bugs and ticks naturally infected with M. leprae still remains to be assessed.

\section{Molecular Epidemiology}

M. leprae strains possess strikingly low levels of genetic diversity $[99,100]$ and the genomic approach has provided insights into the intriguing biology of M. leprae with extensive reductive evolution [101].

Comparative genomics analysis of $M$. leprae strains has identified SNPs which enable to distinguish SNP types 1 to 4 [102]. The remarkable genetic conservation of M. leprae became further evident when four strains from different parts of the world (India, Brazil, Thailand, and USA) were 
compared at the genome level, revealing only a few hundred variants. Upon analyzing these genomic markers in a set of over 400 strains, the phylogeographic association of M. leprae revealed an association of the SNP types with the routes of ancient human migration. These investigations also led to the development of a more robust genotyping schemes comprising of 16 SNP subtypes under the four major SNP types described earlier [45, 103]. Several sets of primers were developed for molecular characterization of strains in endemic countries. Such information has further helped in identifying unique genomic markers specific to a particular genotype, such as the $11 \mathrm{bp}$ deletion at position 17915 in the 3I strains which can be identified even on $2 \%$ agarose gel without any sequencing [50••]. Another approach of identifying locally predominant genotypes such as SNP type 3I in samples from Colombia based on PCR-restriction fragment length polymorphism of the SNP 7614 has been described [58] and similar approach can be developed for SNP type 1D strains, as these are predominant in India [104-106].

However, the limitation of SNP typing for monitoring local transmission dynamics was evident from the fact that most of the strains from a given geographic area belonged to the same SNP type. Hence, for monitoring local transmission, a set of selected VNTRs are considered very useful [107], though some of these VNTR loci can be hyper-variable, i.e., some VNTR loci can differ between different lesions in the same patient [108]. In addition, the use of VNTRs alone has a drawback that deriving a reliable inference regarding which strains are ancestral compared to the others is very difficult. Hence, a combined genotyping scheme using a selected panel of SNPs and VNTRs has been successfully used for confirming the zoonotic link between armadillo and human leprosy in Southern USA [50•, 51].

Recent advents in the next-generation sequencing technologies and target DNA enrichment methods have enabled detailed comparative genomic investigations into a large number of M. leprae strains representing all known SNP types [4, 40, $44,109]$. These approaches allowed to make progress on issues related to relapse and re-infection, which was not feasible even with the combined analysis of SNP genotyping and VNTRs [45].

Studies have shown that dominant strains among humans in Brazil are SNP subtypes 4P and 4N, as well as SNP subtype 3I $[40,110]$. In Colombia, SNP subtype $4 \mathrm{~N}$ is mainly found in the Northeast and Caribbean coast and SNP type 3 in the Andes, according to the origin of the Colombian population [111], while in Venezuela, a majority of human strains are SNP subtype 3I with some 4P, 1D, 4O, and 4N [42, 103]. For the Guiana Shield, a SNP subtype 1A was found in a patient in Guyana [103] and a SNP type 4 in a one-century-old skeleton has been uncovered from a cemetery in a former leprosarium in Suriname [112]. This broad diversity of $M$. leprae genotypes indicates that there have been multiple introductions, e.g., SNP type 3I from Europe likely got introduced during the period of colonialism; SNP type 4 from West Africa likely reached America with the slave trade and SNP type 1 most likely arrived through Asian migrations [103]. Besides, additional admixture was observed inside the SNP type 3I suggesting several introductions from Europe $[40 \bullet \cdot$.

Zoonotic strains in E. sexcinctus in northeastern Brazil and in D. novemcinctus in the Southern USA are reported as SNP type 3 and 3I-2 types respectively [15, 50••, 51]. In the positive $D$. sabanicola found in Venezuela, preliminary results suggest the presence of a mixed genotype infection (3I and 1D) which needs further investigation (A. Paniz-Mondolfi, P. Singh; unpublished data). Interestingly, SNP type 3I is the most prevalent genotype in Venezuelan patients, followed by the 1D genotype, clearly correlating from an epidemiological standpoint. Moreover, genotypes 3I and 1D are also the most prevalent (73\% and 13\% respectively) among clinical specimens in hyperendemic areas [42]. There is currently no information on putative genetic differences of strains circulating in low and high endemic areas at genome level.

Even if it has not yet been described in naturally infected armadillos, the genetically distant SNP type 4P, which is predominant in patients in South America, is capable to experimentally infect and impair armadillo's health similar to the 3I genotype zoonotic strains [113•], suggesting that other human genotypes may have the potential of infecting armadillos. Although not directly detected in armadillos yet, $M$. leprae DNA with SNP type 1 or 2 have been found in armadillo burrow soil in Suriname [77•]. Also, the SNP types of $M$. leprae detected in soil/water samples and the leprosy patients living in those areas are often the same, whether in India [73] or in Brazil [78], which reinforces the hypothesis of an environmental reservoir of $M$. leprae likely contributing in continuous leprosy transmission.

\section{Conclusions}

This is the first time that all studies carried out in this region have been brought together and put into perspective, highlighting the unique characteristics concerning the epidemiology of leprosy in the Amazonian biome and surrounding regions. Pockets of high human leprosy endemicity within global areas of medium endemicity and the presence of armadillos, the most important non-human reservoir of $M$. leprae known to date, characterize leprosy epidemiology in this region. The discovery of the zoonotic nature of leprosy in the USA and the recent identification of another animal reservoir in the British Isles marked the beginning of a renewed interest in the field. It also introduced a new paradigm for leprosy epidemiology, prevention, and control, which shifted from a typically human-only disease, that could theoretically be eradicated, to a zoonotic disease, at least in the Americas, questioning the likelihood of leprosy eradication in a near 
future. Emergence of drug resistance also challenges the leprosy elimination goal. Drug resistance in primary leprosy cases urged health authorities to implement systematic drug susceptibility testing for all leprosy cases. This is especially important in a high endemic area such as Brazil and in countries reporting high relapse case rates, to prevent emergence and transmission of drug-resistant strains. As an example, the Brazilian government have recently implemented a drug resistance surveillance network in which samples are screened centrally in a reference laboratory. Such an initiative should be acknowledged, encouraged, and might be used for future collaboration between the Amazonian countries where drug resistance surveillance is not routinely performed. Besides, the existence of such a laboratory could also allow to use specific techniques such as WGS to be implemented for large-scale studies. So far, only few genomes from South America are available and additional investigation would help to identify bacterial markers possibly linked with relapse and high endemicity. There are still many gaps to fill in order to better characterize the leprosy eco-epidemiology and to evaluate the burden of zoonosis part in leprosy transmission in the Amazonian countries. Broadly speaking, this region offers a unique and promising opportunity to increase our understanding of leprosy agent's eco-epidemiology worldwide.

Acknowledgments We thank Mariella Superina, Toine Pieters, Henk Menke, and Telesphor Abga for additional information, Isabelle Roger and Agathe Chavy for helpful advice, and Heïdi Lançon for the English revision of the manuscript.

Funding Information This work was funded by the European Funds for Regional Development (Feder), No. SYNERGIE GY0012083, the RESERVOIRS project (Synergie GY0009430), and the MicroBIOME project granted by Laboratoire d'Excellence CEBA "Investissement d'Avenir" and managed by the Agence Nationale de la Recherche (CEBA, Ref. ANR-10-LABEX-25-01). This work was also supported by the Heiser Program of the New York Community Trust for Research in Leprosy grant number P18-000250 (CA and JB), the Association de Chimiothérapie Anti-Infectieuse of the Société Française de Microbiologie (CA), the European Union's Horizon 2020 research and innovation program under the Marie Sklodowska-Curie grant no. 845479 (CA), a non-stipendiary European Molecular Biology Organization (EMBO) long-term fellowship grant number ALTF 1086-2018 (CA), the Q.M. Gastmann-Wichers Foundation, and the R2STOP Research grant from effect::hope Canada and The Mission to End Leprosy, Ireland (PS), Leprosy Research Initiative Netherlands (PS).

\section{Compliance with Ethical Standards}

Conflict of Interest The authors declare that they have no conflicts of interest.

Human and Animal Rights and Informed Consent All reported studies/ experiments with human or animal subjects performed by the authors complied with all applicable ethical standards.

Open Access This article is licensed under a Creative Commons Attribution 4.0 International License, which permits use, sharing, adaptation, distribution and reproduction in any medium or format, as long as you give appropriate credit to the original author(s) and the source, provide a link to the Creative Commons licence, and indicate if changes were made. The images or other third party material in this article are included in the article's Creative Commons licence, unless indicated otherwise in a credit line to the material. If material is not included in the article's Creative Commons licence and your intended use is not permitted by statutory regulation or exceeds the permitted use, you will need to obtain permission directly from the copyright holder. To view a copy of this licence, visit http://creativecommons.org/licenses/by/4.0/.

\section{References}

Papers of particular interest, published recently, have been highlighted as:

- Of importance

•• Of major importance

1. Scollard DM, Adams LB, Gillis TP, Krahenbuhl JL, Truman RW, Williams DL. The continuing challenges of leprosy. Clin Microbiol Rev. 2006;19:338-81.

2. Han XY, Seo Y-H, Sizer KC, Schoberle T, May GS, Spencer JS, et al. A new Mycobacterium species causing diffuse lepromatous leprosy. Am J Clin Pathol. 2008;130:856-64.

3. Sharma R, Singh P, McCoy RC, Lenz SM, Donovan K, Ochoa MT, et al. Isolation of Mycobacterium lepromatosis and development of molecular diagnostic assays to distinguish $M$. leprae and $M$. lepromatosis. Clin Infect Dis [Internet]. 2020; [cited 2020 Jan 10]; Available from: https://academic.oup.com/cid/advance-article/doi/10. 1093/cid/ciz1121/5626481.

4. Singh P, Benjak A, Schuenemann VJ, Herbig A, Avanzi C, Busso $\mathrm{P}$, et al. Insight into the evolution and origin of leprosy bacilli from the genome sequence of Mycobacterium lepromatosis. Proc Natl Acad Sci USA. 2015;112:4459-64.

5. Balamayooran G, Pena M, Sharma R, Truman RW. The armadillo as an animal model and reservoir host for Mycobacterium leprae. Clin Dermatol. 2015;33:108-15.

6. World Health Organization. Global leprosy update, 2018: moving towards a leprosy-free world. Wkly Epidemiol Rec. 2019;94:389411.

7. Araujo S, Freitas LO, Goulart LR, Goulart IMB. Molecular evidence for the aerial route of infection of Mycobacterium leprae and the role of asymptomatic carriers in the persistence of leprosy. Clin Infect Dis. 2016;63:1412-20.

8. van Beers SM, Hatta M, Klatser PR. Patient contact is the major determinant in incident leprosy: implications for future control. Int J Lepr Other Mycobact Dis. 1999;67:119-28.

9. Truman R. Leprosy in wild armadillos. Lepr Rev. 2005;76:198 208.

10. 2018 Reference: National Leprosy Elimination Programme annual report 2018. SAIB/MPPS. 2018.

11. Chaitra P, Bhat RM. Postelimination status of childhood leprosy: report from a tertiary-care hospital in South India. Biomed Res Int. 2013;2013:328673.

12. da Silva FJ, de Carvalho FM, Vidal Pessolani MC, de Paula Antunes JMA, de Medeiros Oliveira IVP, Ferreira Moura GH, et al. Serological and molecular detection of infection with Mycobacterium leprae in Brazilian six banded armadillos (Euphractus sexcinctus). Comp Immunol Microbiol Infect Dis. 2020;68:101397. 
13. Stefani MMA, Rosa PS, Costa MB, Schetinni APM, Manhães I, Pontes MAA, et al. Leprosy survey among rural communities and wild armadillos from Amazonas state, Northern Brazil. PLoS ONE [Internet]. 2019;14 [cited 2019 Sep 5] Available from: https://www.ncbi.nlm.nih.gov/pmc/articles/PMC6328080/.

14. da Silva MB, Portela JM, Li W, Jackson M, Gonzalez-Juarrero M, Hidalgo AS, et al. Evidence of zoonotic leprosy in Pará, Brazilian Amazon, and risks associated with human contact or consumption of armadillos. PLoS Negl Trop Dis [Internet]. 2018;12 [cited 2019 Dec 26] Available from: https://www.ncbi.nlm.nih.gov/pmc/ articles/PMC6023134/. Da Silva et al. brought the first proof of wild armadillos naturally infected with Mycobacterium leprae in the Brazilian Amazon.

15. Frota CC, Lima LNC, Rocha A d S, Suffys PN, Rolim BN, Rodrigues LC, et al. Mycobacterium leprae in six-banded (Euphractus sexcinctus) and nine-banded armadillos (Dasypus novemcinctus) in Northeast Brazil. Mem Inst Oswaldo Cruz. 2012;107(Suppl 1):209-13.

16. Pedrini SCB, Rosa PS, Medri IM, Mourão G, Bagagli E, Lopes CA d M. Search for Mycobacterium leprae in wild mammals. Braz J Infect Dis. 2010;14:47-53.

17. Marcelo Azevedo de PAJ, Santos Zanini M, de Castro Demoner L, Duarte Deps P. Diagnóstico de Mycobacterium leprae em tatus (Dasypus novemcinctus) e sua correlação com a proximidade das fontes de água no distrito de Rive, Espírito Santo-Brasil. Veterinária E Zootec. 2009;16:642-9.

18. Deps PD, Antunes JMA d P, Tomimori-Yamashita J. Detection of Mycobacterium leprae infection in wild nine-banded armadillos (Dasypus novemcinctus) using the rapid ML Flow test. Rev Soc Bras Med Trop. 2007;40:86-7.

19. Deps PD, Santos AR, Yamashita-Tomimori J. Detection of Mycobacterium leprae DNA by PCR in blood sample from nine-banded armadillo: preliminary results. Int $\mathrm{J}$ Lepr Other Mycobact Dis. 2002;70:34-5.

20. Cardona-Castro N, Beltrán JC, Ortiz-Bernal A, Vissa V. Detection of Mycobacterium leprae DNA in nine-banded armadillos (Dasypus novemcinctus) from the Andean region of Colombia. Lepr Rev. 2009;80:424-31.

21. Loughry WJ, McDonough CM. The nine-banded armadillo: a natural history. Norman: University of Oklahoma Press; 2013.

22. Schaub R, Pena MT, Walley R, Leclerc L, Simon S, Couppié P, et al. First evidence of Mycobacterium leprae infection in armadillos in French Guiana. Presented at: 20th International Leprosy Congress; 2019 September 11-13; Manila, Philippines.

23. Zumarraga MJ, Resoagli EH, Cicuta ME, Martinez AR, Oritiz de Rott MI, de Millan SG, et al. PCR-restriction fragment length polymorphism analysis (PRA) of Mycobacterium leprae from human lepromas and from a natural case of an armadillo of Corrientes, Argentina. Int J Lepr Other Mycobact Dis. 2001;69: 21-5.

24. Innami S. A study of the armadillo in Paraguay. Washington DD: Pan American Health Organization; 1978. p. 89-95.

25. Barreto JG, Guimarães L d S, Frade MAC, Rosa PS, Salgado CG. High rates of undiagnosed leprosy and subclinical infection amongst school children in the Amazon Region. Mem Inst Oswaldo Cruz. 2012;107:60-7.

26. Pedrosa VL, Dias LC, Galban E, Leturiondo A, Palheta J, Santos $\mathrm{M}$, et al. Leprosy among schoolchildren in the Amazon region: a cross-sectional study of active search and possible source of infection by contact tracing. PLoS Negl Trop Dis. 2018;12:e006261.

27. Taxa de detecção de hanseníase por 100.000 habitantes - Estados e regiões, Brasil, 1990 a 2018. [internet]. Ministério da Saúde do Brasil. [Internet]. Available from: http://portalarquivos2.saude. gov.br/images/pdf/2019/julho/17/Taxa-de-detec\%2D $\% 2 \mathrm{D} \% 2 \mathrm{D} \%$ 2Do-geral-de-hansen \%2D\%2Dase-por-100.000\%20habitantes, $\%$
20Estados\%20e\%20regi\%C3\%B5es,\%20Brasil,\%201990\% 20a\%202018.pdf.

28. Action plan to further advance towards leprosy elimination in Latin America and the Caribbean [Internet]. PAHO; 2011. Available from: https://www.paho.org/hq/dmdocuments/2011/ 2011-cha-paho-leprosy-plan.pdf.

29. Cardona-Castro N. Leprosy in Colombia. Curr Trop Med Rep. 2018;5:85-90.

30. Convit J, Borges R, Ulrich M, Aranzazu N, Pinardi ME, Parra JJ. Vacinas para a Hanseníase. Hansen Int. 2003;28:13-8.

31. Graille J, Blaizot R, Darrigade AS, Sainte-Marie D, Nacher M, Schaub R, et al. Leprosy in French Guiana 2007-2014: a reemerging public health problem. Br J Dermatol. 2019.

32. Douine M, Mosnier E, Le Hingrat Q, Charpentier C, Corlin F, Hureau L, et al. Illegal gold miners in French Guiana: a neglected population with poor health. BMC Public Health [Internet]. 2017;18 [cited 2019 Dec 26] Available from: https://www.ncbi. nlm.nih.gov/pmc/articles/PMC5513330/.

33. Kurup R, Haynes U, Mentore G. A study on trends and patterns of leprosy in Guyana during a ten year period, 2007-2016. Indian J Lepr. 2018;90:207-16.

34. WHO Study Group on Chemotherapy of Leprosy. Chemotherapy of leprosy: report of a WHO study group [meeting held in Geneva from 1 to 5 November 1993] [Internet]. 1994. Geneva: World Health Organization; 1993. Available from: https://apps.who.int/ iris/handle/10665/39877

35.• Cambau E, Saunderson P, Matsuoka M, Cole ST, Kai M, Suffys P, et al. Antimicrobial resistance in leprosy: results of the first prospective open survey conducted by a WHO surveillance network for the period 2009-15. Clin Microbiol Infect. 2018;24:1305-10. This study reports Mycobacterium leprae antimicrobial resistance level in 19 countries including two from the Amazon.

36. Guidelines for the diagnosis, treatment and prevention of leprosy. New Delhi: World Health Organization, Regional Office for South-East Asia; 2017. Licence: CC BY-NC-SA 3.0 IGO.

37. A guide for surveillance of antimicrobial resistance in leprosy: 2017 update. New Delhi: World Health Organization, Regional Office for South-East Asia; 2017. Licence: CC BY-NC-SA 3.0 IGO.

38. Beltrán-Alzate C, López Díaz F, Romero-Montoya M, Sakamuri $\mathrm{R}, \mathrm{Li} \mathrm{W}$, Kimura M, et al. Leprosy drug resistance surveillance in Colombia: the experience of a sentinel country. PLoS Negl Trop Dis. 2016;10:e0005041.

39. Rocha A d S, Cunha M d G, Diniz LM, Salgado C, Aires MAP, Nery JA, et al. Drug and multidrug resistance among Mycobacterium leprae isolates from Brazilian relapsed leprosy patients. J Clin Microbiol. 2012;50:1912-7.

40.• Benjak A, Avanzi C, Singh P, Loiseau C, Girma S, Busso P, et al. Phylogenomics and antimicrobial resistance of the leprosy bacillus Mycobacterium leprae. Nat Commun. 2018;9:1-11. Benjak et al give the overall picture of $M$. leprae diversity at genome level in more than 20 countries worldwide and identified new markers of pathogenicity and resistance.

41. Rosa PS, D'Espindula HRS, Melo ACL, Fontes ANB, Finardi AJ, Belone AFF, et al. Emergence and transmission of drug/multidrug-resistant Mycobacterium leprae in a former leprosy colony in the Brazilian Amazon. Clin Infect Dis. 2019.

42. Singh P, Busso P, Paniz-Mondolfi A, Aranzazu N, Monot M, Honore N, et al. Molecular drug susceptibility testing and genotyping of Mycobacterium leprae strains from South America. Antimicrob Agents Chemother. 2011;55:2971-3.

43. Gonçalves FG, Belone A d FF, Rosa PS, Laporta GZ. Underlying mechanisms of leprosy recurrence in the Western Amazon: a retrospective cohort study. BMC Infect Dis. 2019;19:460.

44. Avanzi C, Busso P, Benjak A, Loiseau C, Fomba A, Doumbia G, et al. Transmission of drug-resistant leprosy in Guinea-Conakry 
detected using molecular epidemiological approaches. Clin Infect Dis. 2016;63:1482-4.

45. Stefani MMA, Avanzi C, Bührer-Sékula S, Benjak A, Loiseau C, Singh $\mathrm{P}$, et al. Whole genome sequencing distinguishes between relapse and reinfection in recurrent leprosy cases. PLoS Negl Trop Dis. 2017;11:e0005598.

46. Walsh GP, Storrs EE, Burchfield HP, Cotrell EH, Vidrine MF, Binford CH. Leprosy-like disease occurring naturally in armadillos. J Reticuloendothel Soc. 1975;18:347-51.

47. Amezcua ME, Escobar-Gutiérrez A, Storrs EE, Dhople AM, Burchfield HP. Wild Mexican armadillo with leprosy-like infection. Int J Lepr Other Mycobact Dis. 1984;52:254-5.

48. Deps PD, Alves BL, Gripp CG, Aragao RL, Guedes B, Filho JB, et al. Contact with armadillos increases the risk of leprosy in Brazil: a case control study. Indian J Dermatol Venereol Leprol. 2008;74:338-42.

49. Zumarraga MJ, Resoagli EH, Cicuta ME, Martinez AR, Oritiz de Rott MI, de Millan SG, et al. PCR-restriction fragment length polymorphism analysis (PRA) of Mycobacterium leprae from human lepromas and from a natural case of an armadillo of Corrientes, Argentina. Int J Lepr Other Mycobact Dis. 2001;69: $21-5$.

50.• Truman RW, Singh P, Sharma R, Busso P, Rougemont J, PanizMondolfi A, et al. Probable zoonotic leprosy in the southern United States. N Engl J Med. 2011;364:1626-33. This study establishes the first proof of leprosy as a zoonosis disease between armadillo and human.

51. Sharma R, Singh P, Loughry WJ, Lockhart JM, Inman WB, Duthie MS, et al. Zoonotic leprosy in the southeastern United States. Emerg Infect Dis. 2015;21:2127-34.

52. Oli MK, Loughry WJ, Caswell H, Perez-Heydrich C, McDonough CM, Truman RW. Dynamics of leprosy in ninebanded armadillos: net reproductive number and effects on host population dynamics. Ecol Model. 2017;350:100-8.

53. Santos PM, Bocchiglieri A, Chiarello AG, Paglia AP, Moreira A, de Souza AC, et al. NEOTROPICAL XENARTHRANS: a data set of occurrence of xenarthran species in the Neotropics. Ecology. 2019; 100:e02663.

54. Hautier L, Billet G, de Thoisy B, Delsuc F. Beyond the carapace: skull shape variation and morphological systematics of longnosed armadillos (genus Dasypus). PeerJ. 2017;5:e3650.

55. Baliña LM, Valdez RP, de Herrera M, Costa Cordova H, Bellocq J, Garcia N. Experimental reproduction of leprosy in seven-banded armadillos (Dasypus hybridus). Int J Lepr Other Mycobact Dis. 1985;53:595-9.

56. Kerr L, Kendall C, de Sousa CAB, Frota CC, Graham J, Rodrigues L, et al. Human-armadillo interaction in Ceará, Brazil: potential for transmission of Mycobacterium leprae. Acta Trop. 2015;152:74-9.

57. Domozych R, Kim E, Hart S, Greenwald J. Increasing incidence of leprosy and transmission from armadillos in Central Florida: a case series. JAAD Case Rep. 2016;2:189-92.

58. Cardona-Castro N, Beltrán-Alzate JC, Romero-Montoya IM, Li W, Brennan PJ, Vissa V. Mycobacterium leprae in Colombia described by SNP7614 in gyrA, two minisatellites and geography. Infect Genet Evol. 2013;14:375-82.

59. Deps PD, Faria LV, Gonçalves VC, Silva DA, Ventura CG, Zandonade E. Aspectos epidemiológicos da transmissão da hanseníase em relação a exposição ao tatu. Hansen Int Online. 2003;28:138-44.

60. Kerr-Pontes LR, Barreto ML, Evangelista CM, Rodrigues LC, Heukelbach J, Feldmeier H. Socioeconomic, environmental, and behavioural risk factors for leprosy in North-east Brazil: results of a case-control study. Int J Epidemiol. 2006;35:994-1000.
61. Clark BM, Murray CK, Horvath LL, Deye GA, Rasnake MS, Longfield RN. Case-control study of armadillo contact and Hansen's disease. Am J Trop Med Hyg. 2008;78:962-7.

62. Schmitt JV, Dechandt IT, Dopke G, Ribas ML, Cerci FB, Viesi JMZ, et al. Armadillo meat intake was not associated with leprosy in a case control study, Curitiba (Brazil). Mem Inst Oswaldo Cruz. 2010;105:857-62.

63. Joyce MP. Historic aspects of human susceptibility to leprosy and the risk of conjugal transmission. Mem Inst Oswaldo Cruz. 2012;107:17-21.

64. Bratschi MW, Steinmann P, Wickenden A, Gillis TP. Current knowledge on Mycobacterium leprae transmission: a systematic literature review. Lepr Rev. 2015;86:142-55.

65. Cambri G, Mira MT. Genetic susceptibility to leprosy-from classic immune-related candidate genes to hypothesis-free, whole genome approaches. Front Immunol [Internet]. 2018;9 [cited 2020 Jan 30] Available from: https://www.frontiersin.org/articles/10. 3389/fimmu.2018.01674/full.

66. Wong SH, Gochhait S, Malhotra D, Pettersson FH, Teo YY, Khor $\mathrm{CC}$, et al. Leprosy and the adaptation of human Toll-like receptor 1. PLoS Pathog [Internet]. 2010;6 [cited 2020 Jan 30] Available from: https://www.ncbi.nlm.nih.gov/pmc/articles/PMC2895660/.

67. Alter A, Alcaïs A, Abel L, Schurr E. Leprosy as a genetic model for susceptibility to common infectious diseases. Hum Genet. 2008;123:227-35.

68. Uaska Sartori PV, Penna GO, Bührer-Sékula S, Pontes MAA, Gonçalves HS, Cruz R, et al. Human genetic susceptibility of leprosy recurrence. Sci Rep. 2020;10:1284.

69. Perez-Heydrich C, Loughry WJ, Anderson CD, Oli MK. Patterns of Mycobacterium leprae infection in wild nine-banded armadillos (Dasypus novemcinctus) in Mississippi, USA. J Wildl Dis. 2016;52:524-32.

70.• Avanzi C, del-Pozo J, Benjak A, Stevenson K, Simpson VR, Busso P, et al. Red squirrels in the British Isles are infected with leprosy bacilli. Science. 2016;354:744-7. The study reports a new animal reservoir for the leprosy bacilli, the red squirrel, in a non endemic part of the world, the British Isles. This is the first animal host for $M$. lepromatosis.

71. Olson DM, Dinerstein E, Wikramanayake ED, Burgess ND, Powell GVN, Underwood EC, et al. Terrestrial ecoregions of the world: a new map of life on Earth. A new global map of terrestrial ecoregions provides an innovative tool for conserving biodiversity. BioScience. 2001;51:933-8.

72. Maruyama FH, Morgado TO, Pacheco RC, Nakazato L, Dutra V, Maruyama FH, et al. Molecular detection of Mycobacterium leprae by polymerase chain reaction in captive and free-ranging wild animals. Braz J Infect Dis. 2018;22:445-7.

73. Turankar RP, Lavania M, Singh M, Siva Sai KSR, Jadhav RS. Dynamics of Mycobacterium leprae transmission in environmental context: deciphering the role of environment as a potential reservoir. Infect Genet Evol. 2012;12:121-6.

74. Turankar RP, Lavania M, Chaitanya VS, Sengupta U, Darlong J, Darlong F, et al. Single nucleotide polymorphism-based molecular typing of M. leprae from multicase families of leprosy patients and their surroundings to understand the transmission of leprosy. Clin Microbiol Infect. 2014;20:O142-9.

75. Mohanty PS, Naaz F, Katara D, Misba L, Kumar D, Dwivedi DK, et al. Viability of Mycobacterium leprae in the environment and its role in leprosy dissemination. Indian J Dermatol Venereol Leprol. 2016;82:23-7.

76. Turankar RP, Lavania M, Darlong J, Siva Sai KSR, Sengupta U, Jadhav RS. Survival of Mycobacterium leprae and association with Acanthamoeba from environmental samples in the inhabitant areas of active leprosy cases: a cross sectional study from endemic pockets of Purulia, West Bengal. Infect Genet Evol [Internet]. 
2019; [cited 2019 Feb 1]; Available from: http://www. sciencedirect.com/science/article/pii/S1567134819300012.

77. Tió-Coma M, Wijnands T, Pierneef L, Schilling AK, Alam K, Roy JC, et al. Detection of Mycobacterium leprae DNA in soil: multiple needles in the haystack. Sci Rep. 2019;9:1-7. This is the first study showing the detection of Mycobacterium leprae in armadillo burrow soil. Armadillo burrow soil sampling which is easier compared to animal sampling in certain conditions, might thus be used as a proxy of wild armadillo leprosy studies.

78. de Holanda MV, Marques LEC, de Macedo MLB, Pontes MA d A, Sabadia JAB, Kerr LRFS, et al. Presence of Mycobacterium leprae genotype 4 in environmental waters in Northeast Brazil. Rev Soc Bras Med Trop. 2017;50:216-22.

79. Arraes MLB d M, Holanda MV d, Lima LNGC, Sabadia JAB, Duarte CR, Almeida RLF, et al. Natural environmental water sources in endemic regions of northeastern Brazil are potential reservoirs of viable Mycobacterium leprae. Mem Inst Oswaldo Cruz. 2017;112:805-11.

80. Desikan KV, Sreevatsa. Effect of adverse environmental conditions on Mycobacterium leprae. Indian J Clin Biochem. 1997;12:89-92.

81. Albuquerque P, Nicola AM, Magnabosco DAG, Derengowski L d S, Crisóstomo LS, Xavier LCG, et al. A hidden battle in the dirt: soil amoebae interactions with Paracoccidioides spp. PLoS Negl Trop Dis [Internet]. 2019;13 [cited 2019 Nov 13] Available from: https://www.ncbi.nlm.nih.gov/pmc/articles/PMC6797224/.

82. Lahiri R, Krahenbuhl JL. The role of free-living pathogenic amoeba in the transmission of leprosy: a proof of principle. Lepr Rev. 2008;79:401-9.

83. Wheat WH, Casali AL, Thomas V, Spencer JS, Lahiri R, Williams DL, et al. Long-term survival and virulence of Mycobacterium leprae in amoebal cysts. PLoS Negl Trop Dis. 2014;8:e3405.

84. Metzger MJ, Bunce RGH, Jongman RHG, Sayre R, Trabucco A, Zomer R. A high-resolution bioclimate map of the world: a unifying framework for global biodiversity research and monitoring. Glob Ecol Biogeogr. 2013;22:630-8.

85. Desikan KV, Sreevatsa. Extended studies on the viability of Mycobacterium leprae outside the human body. Lepr Rev. 1995;66:287-95.

86. Neumann A d S, Dias F d A, Ferreira J d S, Fontes ANB, Rosa PS, Macedo RE, et al. Experimental infection of Rhodnius prolixus (Hemiptera, Triatominae) with Mycobacterium leprae indicates potential for leprosy transmission. PLoS One. 2016;11:e0156037.

87. Lainson R, Shaw JJ, Fraiha H, Miles MA, Draper CC. Chagas's disease in the Amazon Basin: 1. Trypanosoma cruzi infections in silvatic mammals, triatomine bugs and man in the State of Pará, north Brazil. Trans R Soc Trop Med Hyg. 1979;73:193-204.

88. Johnson CM, Rivas GT. La enfermedad de Chagas en Panamá. Mendoza. 1935;I:245-51. Available from: http://www.gorgas. gob.pa/BiblioGorgas/pdf/La\%20Enfermedad\%20de\% 20Chagas\%20en\%20Panama\%20Car1\%20M\%20Johnson\% 20Carlos\%20T\%20de\%20Rivas..pdf.

89. Sarquis O, Carvalho-Costa FA, Oliveira LS, Duarte R, D Andrea PS, de Oliveira TG, et al. Ecology of Triatoma brasiliensis in northeastern Brazil: seasonal distribution, feeding resources, and Trypanosoma cruzi infection in a sylvatic population. J Vector Ecol. 2010;35:385-94.

90. de CM de Souza R, Soares AC, Alves CL, Lorosa ES, Pereira MH, Diotaiuti L. Feeding behavior of Triatoma vitticeps (Reduviidae: Triatominae) in the state of Minas Gerais. Brazil Mem Inst Oswaldo Cruz. 2011;106:16-22.
91. Farfán-García AE, Angulo-Silva VM. Conducta alimentaria de poblaciones de Triatoma dimidiata (Hemiptera: Reduviidae: Triatominae) en una zona endémica y sus implicaciones epidemiológicas. Rev Salud Pública. 2011;13:163-72.

92. Orozco MM, Enriquez GF, Alvarado-Otegui JA, Cardinal MV, Schijman AG, Kitron U, et al. New sylvatic hosts of Trypanosoma cruzi and their reservoir competence in the humid Chaco of Argentina: a longitudinal study. Am J Trop Med Hyg. 2013;88:872-82.

93. Gaunt M, Miles M. The ecotopes and evolution of triatomine bugs (triatominae) and their associated trypanosomes. Mem Inst Oswaldo Cruz. 2000;95:557-65.

94. Pinho AP, Gonçalves TCM, Mangia RH, Russell NSN, Jansen AM. The occurrence of Rhodnius prolixus Stal, 1859, naturally infected by Trypanosoma cruzi in the State of Rio de Janeiro, Brazil (Hemiptera, Reduviidae, Triatominae). Mem Inst Oswaldo Cruz. 1998;93:141-3.

95. Soares HS, Barbieri ARM, Martins TF, Minervino AHH, de Lima JTR, Marcili A, et al. Ticks and rickettsial infection in the wildlife of two regions of the Brazilian Amazon. Exp Appl Acarol. 2015;65:125-40.

96. Kluyber D, Martins TF, Desbiez AJL, Amorim M, Massocato G, Labruna MB. Ticks (Acari: Ixodidae) infesting armadillos (Cingulata: Dasypodidae) in the Pantanal wetland, Mato Grosso do Sul, Brazil. Syst Appl Acarol. 2016;21:1087-91.

97. Binetruy F, Chevillon C, de Thoisy B, Garnier S, Duron O. Survey of ticks in French Guiana. Ticks Tick-Borne Dis. 2019;10:77-85.

98. Ferreira J d S, Souza Oliveira DA, Santos JP, Ribeiro CCDU, Baêta BA, Teixeira RC, et al. Ticks as potential vectors of Mycobacterium leprae: use of tick cell lines to culture the bacilli and generate transgenic strains. PLoS Negl Trop Dis. 2018;12: $\mathrm{e} 0007001$.

99. Williams DL, Gillis TP, Portaels F. Geographically distinct isolates of Mycobacterium leprae exhibit no genotypic diversity by restriction fragment-length polymorphism analysis. Mol Microbiol. 1990;4:1653-9.

100. Clark-Curtiss JE, Walsh GP. Conservation of genomic sequences among isolates of Mycobacterium leprae. J Bacteriol. 1989;171: 4844-51.

101. Cole ST, Eiglmeier K, Parkhill J, James KD, Thomson NR, Wheeler PR, et al. Massive gene decay in the leprosy bacillus. Nature. 2001;409:1007-11.

102. Monot M, Honoré N, Garnier T, Araoz R, Coppée J-Y, Lacroix C, et al. On the origin of leprosy. Science. 2005;308:1040-2.

103. Monot M, Honoré N, Garnier T, Zidane N, Sherafi D, PanizMondolfi A, et al. Comparative genomic and phylogeographic analysis of Mycobacterium leprae. Nat Genet. 2009;41:1282-9.

104. Lavania M, Singh I, Turankar RP, Ahuja M, Pathak V, Sengupta $\mathrm{U}$, et al. Molecular detection of multidrug-resistant Mycobacterium leprae from Indian leprosy patients. J Glob Antimicrob Resist. 2018;12:214-9.

105. Das M, Chaitanya VS, Kanmani K, Rajan L, Ebenezer M. Genomic diversity in Mycobacterium leprae isolates from leprosy cases in South India. Infect Genet Evol. 2016;45:285-9.

106. Kuruwa S, Vissa V, Mistry N. Distribution of Mycobacterium leprae strains among cases in a rural and urban population of Maharashtra, India. J Clin Microbiol. 2012;50:1406-11.

107. Groathouse NA, Rivoire B, Kim H, Lee H, Cho S-N, Brennan PJ, et al. Multiple polymorphic loci for molecular typing of strains of Mycobacterium leprae. J Clin Microbiol. 2004;42:1666-72. 
108. Monot M, Honoré N, Balière C, Ji B, Sow S, Brennan PJ, et al. Are variable-number tandem repeats appropriate for genotyping Mycobacterium leprae? J Clin Microbiol. 2008;46:2291-7.

109. Schuenemann VJ, Singh P, Mendum TA, Krause-Kyora B, Jäger $\mathrm{G}$, Bos KI, et al. Genome-wide comparison of medieval and modern Mycobacterium leprae. Science. 2013;341:179-83.

110. Fontes ANB, Gomes HM, de Araujo MI, de Albuquerque ECA, Baptista IMFD, Moura MM d F, et al. Genotyping of Mycobacterium leprae present on Ziehl-Neelsen-stained microscopic slides and in skin biopsy samples from leprosy patients in different geographic regions of Brazil. Mem Inst Oswaldo Cruz. 2012;107(Suppl 1):143-9.

111. Cardona-Castro N, Beltrán-Alzate JC, Romero-Montoya IM, Meléndez E, Torres F, Sakamuri RM, et al. Identification and comparison of Mycobacterium leprae genotypes in two geographical regions of Colombia. Lepr Rev. 2009;80:316-21.
112. Van Dissel JT, Pieters T, Geluk A, Maat G, Menke HE, Tió-Coma M, et al. Archival, paleopathological and aDNA-based techniques in leprosy research and the case of Father Petrus Donders at the Leprosarium 'Batavia', Suriname. Int J Paleopathol. 2019;27:1-8.

113. Sharma R, Singh P, Pena M, Subramanian R, Chouljenko V, Kim $\mathrm{J}$, et al. Differential growth of Mycobacterium leprae strains (SNP genotypes) in armadillos. Infect Genet Evol. 2018;62:20-6. Sharma et al. experimentally infected armadillos with SNP type 4 Mycobacterium leprae, which has not yet been found in wild armadillos, but is the most prevalent SNP type in South America. They show that SNP type 4 can affect wild armadillos similarly as the zoonotic strains in the USA.

Publisher's Note Springer Nature remains neutral with regard to jurisdictional claims in published maps and institutional affiliations.

\section{Affiliations}

Roxane Schaub ${ }^{1,2}$ (1) $\cdot$ Charlotte Avanzi ${ }^{3,4} \cdot$ Pushpendra Singh $^{5,6} \cdot$ Alberto Paniz-Mondolfi $^{7,8} \cdot$ Nora Cardona-Castro $^{9}$. Pedro Legua ${ }^{10}$. Lucibel Crespo $^{11}$. Karin Sewpersad ${ }^{12}$. John Jairo Dávila ${ }^{13}$. Josafá Barreto ${ }^{14}$. Purna Dwivedi ${ }^{5}$. Heather Morris-Wilson ${ }^{15} \cdot$ Maria Paredes Larrea ${ }^{16,17} \cdot$ Carolina Talhari $^{18} \cdot$ Ramanuj Lahiri $^{19} \cdot$ Richard W. Truman $^{20}$. Rodolphe E. Gozlan ${ }^{21}$ • Pierre Couppié ${ }^{2,22} \cdot$ Benoit de Thoisy ${ }^{23}$

1 CIC AG/Inserm 1424, Centre Hospitalier de Cayenne Andrée Rosemon, Cayenne, French Guiana

2 Laboratoire des Ecosystèmes Amazoniens et Pathologie Tropicale (EPaT) EA 3593, Université de Guyane, Labex CEBA, DFR Santé, Cayenne, French Guiana

3 Mycobacteria Research Laboratories, Department of Microbiology, Immunology and Pathology, Colorado State University, Fort Collins, CO, USA

4 Swiss Tropical and Public Health Institute, Basel, Switzerland

5 National Institute of Research in Tribal Health (Indian Council of Medical Research), Jabalpur, India

6 The Maharaja Sayajirao University of Baroda, Vadodara, Gujarat, India

7 Laboratory of Medical Microbiology, Department of Pathology, Molecular and Cell based Medicine, Icahn School of Medicine at Mount Sinai, New York, NY, USA

8 Instituto de Investigaciones Biomédicas IDB / Incubadora Venezolana de la Ciencia, Cabudare, Lara, Venezuela

9 Instituto Colombiano de Medicina Tropical, Facultad de Medicina, Escuela de Graduados, Universidad CES, Medellín, Colombia

10 Instituto de Medicina Tropical "Alexander von Humboldt", Universidad Peruana Cayetano Heredia, Lima, Peru

11 Servicio de Dermatologia, Instituto de Biomedicina Dr. Jacinto Convit, Caracas, Venezuela
12 Dermatological Service, Ministry of Health Suriname, Paramaribo, Suriname

13 Department of Dermatology, Central University of Ecuador, Quito, Ecuador

14 Spatial Epidemiology Laboratory and Dermato-Immunology Laboratory, Federal University of Pará, Castanhal, Pará, Brazil

15 Leprosy Programme, Ministry of Public Health, Georgetown, Guyana

16 Sociedad Boliviana de Dermatología, La Paz, Bolivia

17 Caja Nacional de Salud, Policlínico Central, La Paz, Bolivia

18 Tropical Dermatology Department, Alfredo da Matta Foundation for Dermatology and Venereoloy, Manaus, Amazonas, Brazil

19 Department of Health and Human Services, Health Resources and Services Administration, Healthcare Systems Bureau, National Hansen's Disease Programs, Baton Rouge, LA, USA

20 Department of Pathobiological Sciences, School of Veterinary Medicine, Louisiana State University, Baton Rouge, LA, USA

21 Institut de Recherche pour le Développement (IRD), UMR 210 Eco\&sols, Montpellier, France

22 Service de Dermatologie, Centre Hospitalier de Cayenne Andrée Rosemon, Cayenne, French Guiana

23 Laboratoire des Interactions Virus-Hôtes, Institut Pasteur de la Guyane, Cayenne, French Guiana 